Supporting Information

\title{
Formation Energetics and Guest - Host Interactions of Molybdenum Carbide Confined in Zeolite Y
}

Xianghui Zhang a,b, Margaret E. Reece ${ }^{\mathrm{a}, \mathrm{c}}$, Cody B. Cockreham ${ }^{\mathrm{a}, \mathrm{b}, \mathrm{d}}$, Hui Sun ${ }^{\mathrm{e}, \mathrm{f}}$, Baodong Wang ${ }^{\mathrm{g}}$, Hongwu Xu ${ }^{\text {d }}$, Junming Sun ${ }^{\text {b }}$, Xiaofeng Guo ${ }^{\text {a,c,h }}, \mathrm{Ha} \mathrm{Su}^{\mathrm{b}}$, Yong Wang ${ }^{\text {b,i }}$, Di Wu ${ }^{\text {a,b,c,h, }, *}$

a Alexandra Navrotsky Institute for Experimental Thermodynamics, Washington State University, Pullman, Washington 99163, United States

${ }^{b}$ The Gene and Linda Voiland School of Chemical Engineering and Bioengineering, Washington State University, Pullman, Washington 99163, United States

${ }^{\mathrm{c}}$ Department of Chemistry, Washington State University, Pullman, Washington 99163, United States

${ }^{\mathrm{d}}$ Earth and Environmental Sciences Division, Los Alamos National Laboratory, Los Alamos, New Mexico 87545

${ }^{\mathrm{e}}$ Petroleum Processing Research Center, East China University of Science and Technology, Shanghai 200237, China

${ }^{\mathrm{f}}$ International Joint Research Center of Green Energy Chemical Engineering, East China University of Science and Technology, Shanghai 200237, China g National Institute of Clean-and-Low-Carbon Energy, Beijing, 102211, China

${ }^{\mathrm{h}}$ Materials Science and Engineering, Washington State University, Pullman, Washington 99163, United States

${ }^{i}$ Institute for Integrated Catalysis, Pacific Northwest National Laboratory, Richland, Washington 99163, United States

Corresponding Author Email:

DiWu,d.wu@wsu.edu 


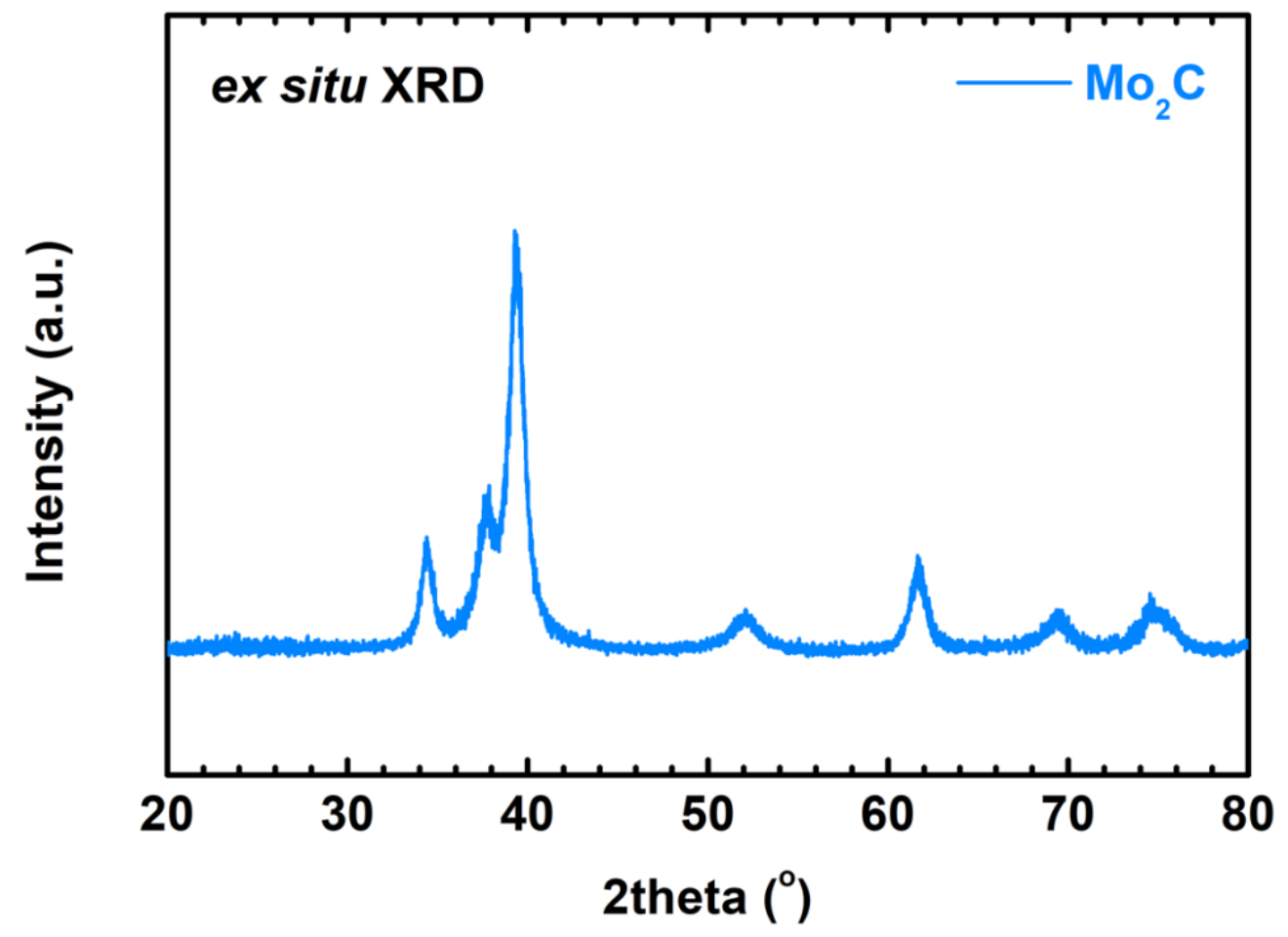

Figure S1. XRD patterns of $\mathrm{Mo}_{2} \mathrm{C}$ prepared by carburization in $15 \mathrm{vol} \% \mathrm{CH}_{4} / \mathrm{H}_{2}$ at $700{ }^{\circ} \mathrm{C}$ for 2 hours.

The XRD patterns of $\mathrm{Mo}_{2} \mathrm{C}$ prepared under the same carburization condition as that used for $\mathrm{Mo}_{2} \mathrm{C} / \mathrm{FAU}$ present typical pattern of $\beta-\mathrm{Mo}_{2} \mathrm{C}$. The peaks at $34.2^{\circ}, 37.8^{\circ}, 39.3^{\circ}, 51.9^{\circ}, 61.2^{\circ}$, $69.3^{\circ}$ and $74.2^{\circ}$ are from the (002), (200), (102), (202), (023), (302) and (223) of $\beta-\mathrm{Mo}_{2} \mathrm{C}$, respectively. The high crystallinity of $\mathrm{Mo}_{2} \mathrm{C}$ suggests that the carburization used favors $\mathrm{Mo}_{2} \mathrm{C}$ formation. 
a

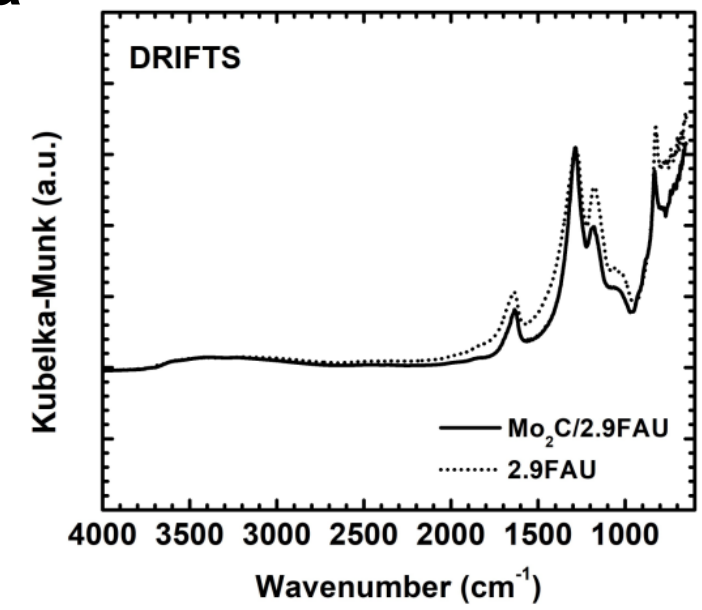

C

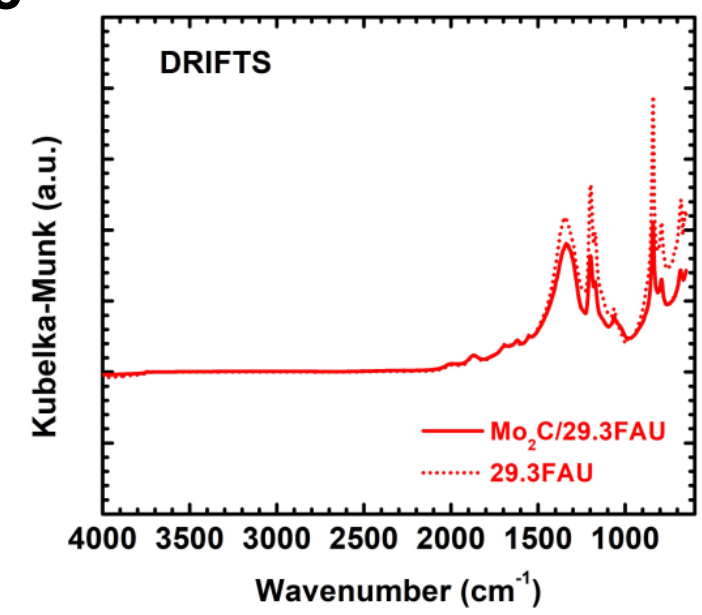

b

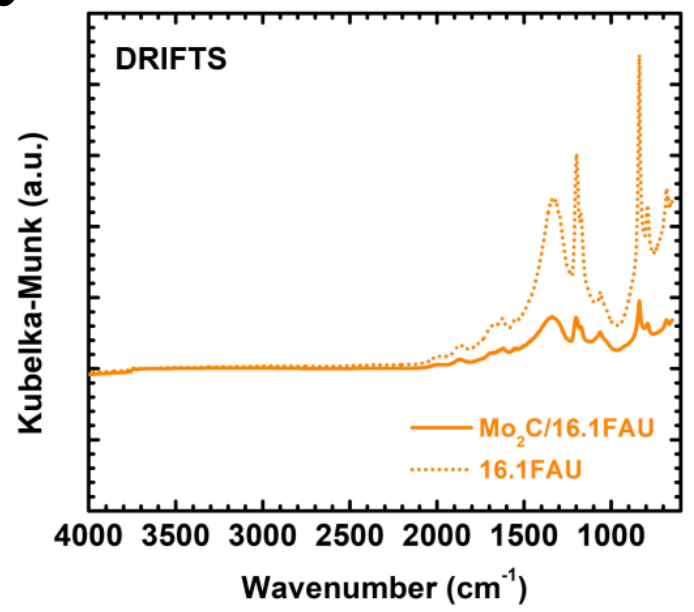

d

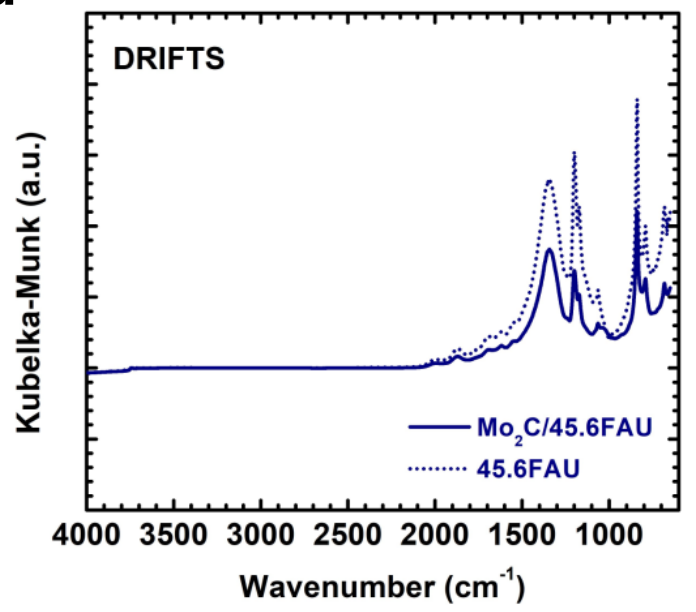

Figure S2. Full range ex situ DRIFTS data of all $\mathrm{Mo}_{2} \mathrm{C} / \mathrm{FAU}$ samples, (a) $\mathrm{Mo}_{2} \mathrm{C} / 2.9 \mathrm{FAU}$, (b) $\mathrm{Mo}_{2} \mathrm{C} / 16.1 \mathrm{FAU}$, (c) $\mathrm{Mo}_{2} \mathrm{C} / 29.3 \mathrm{FAU}$, and (d) $\mathrm{Mo}_{2} \mathrm{C} / 45.6 \mathrm{FAU}$. The spectra of FAU samples are also plotted for comparison. 


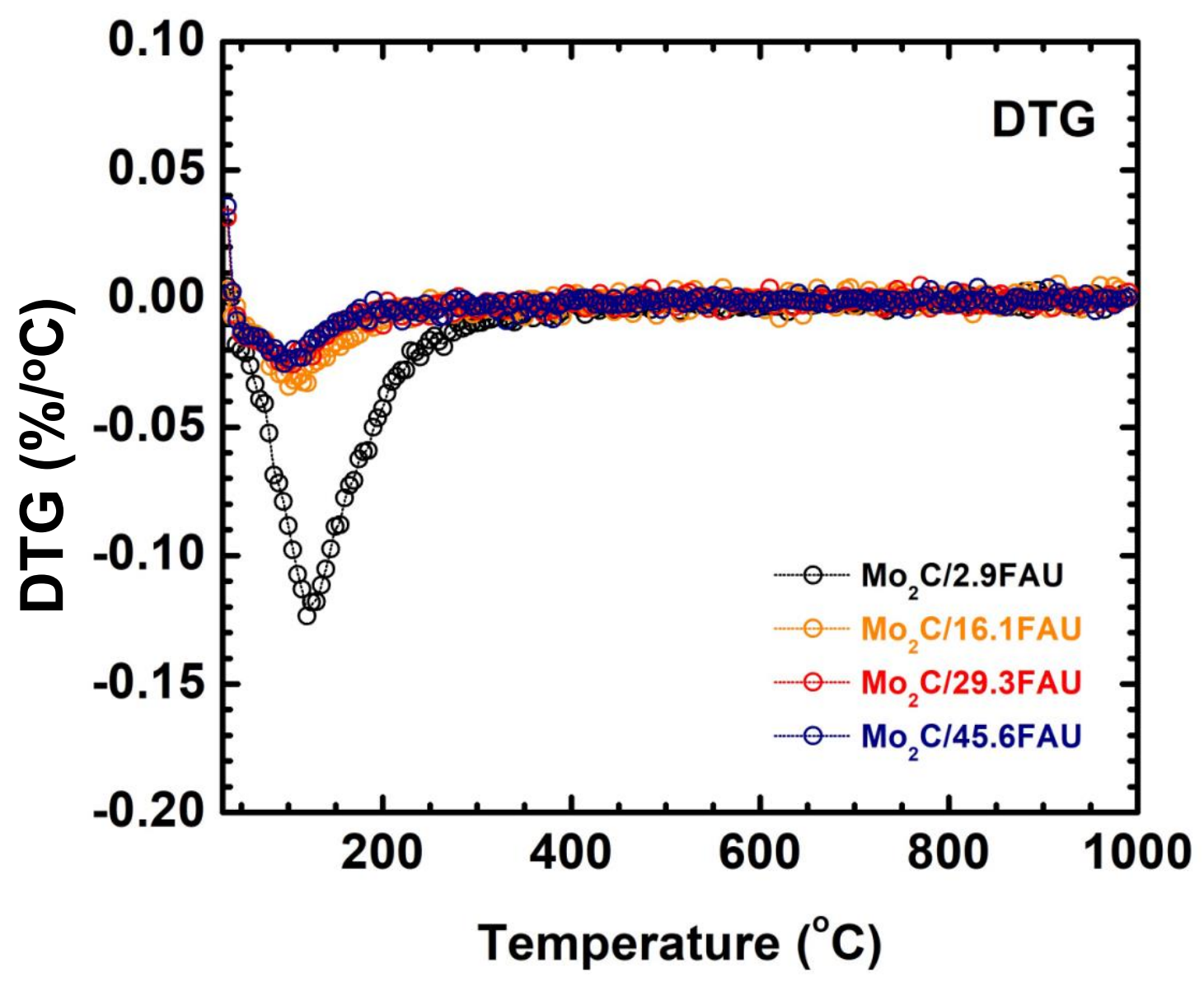

Figure S3. The DTG plots of all $\mathrm{Mo}_{2} \mathrm{C} / \mathrm{FAU}$ samples. Thermal analysis using TG-DSC-MS were performed with $\mathrm{N}_{2}$ flow at $50 \mathrm{~mL} / \mathrm{min}$ from 30 to $1000^{\circ} \mathrm{C}$. 


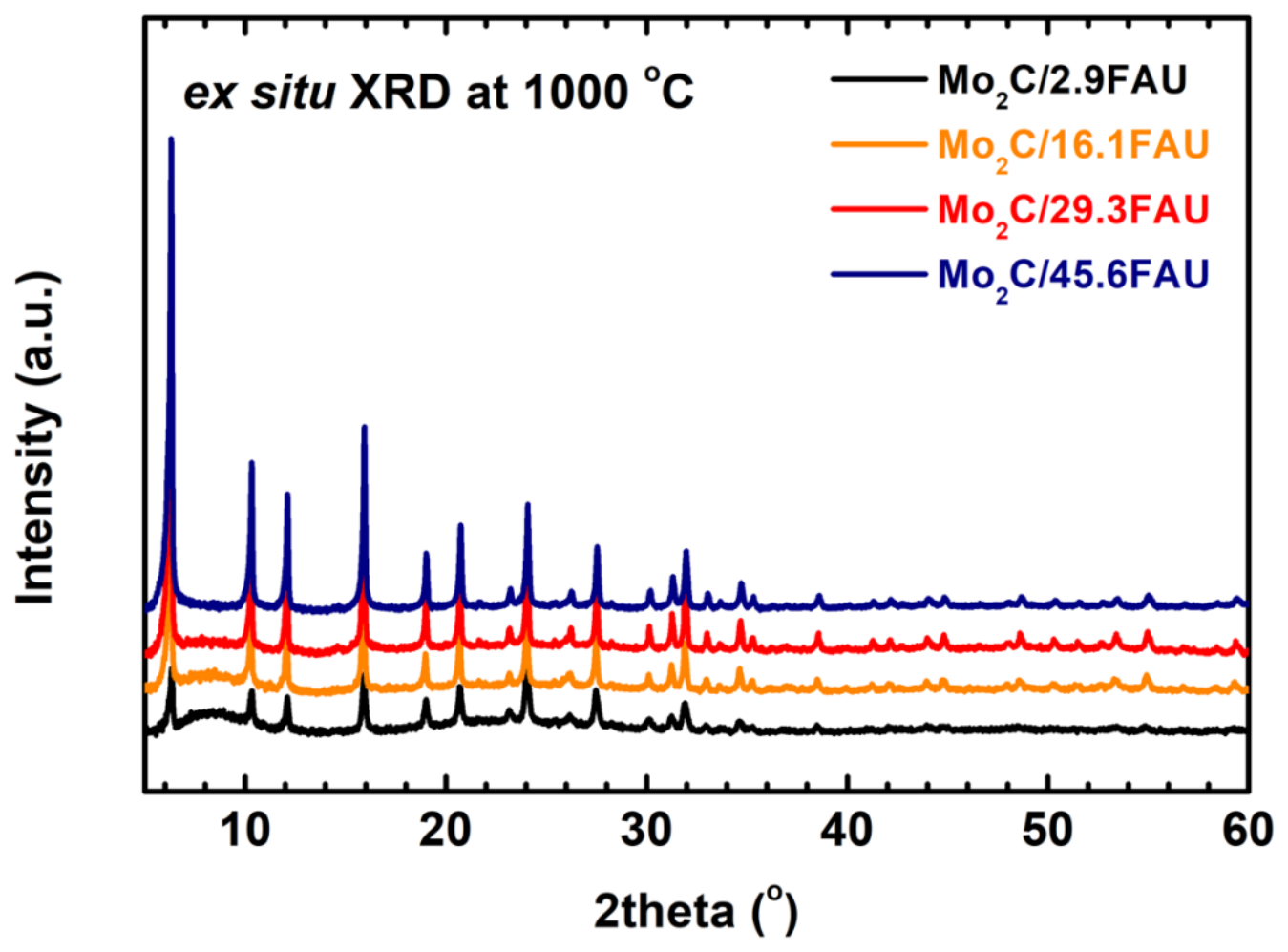

Figure S4. Room temperature ex situ XRD patterns of $\mathrm{Mo}_{2} \mathrm{C} / \mathrm{FAU}$ after thermal analysis at 1000 ${ }^{\circ} \mathrm{C}$. Thermal analysis using TG-DSC-MS were performed with $\mathrm{N}_{2}$ flow at $50 \mathrm{~mL} / \mathrm{min}$ from 30 to $1000{ }^{\circ} \mathrm{C}$. 
Table S1. Drop solution enthalpies for constituent oxides, carbides and water in molten lead borate at $700{ }^{\circ} \mathrm{C}$, and the formation enthalpies from elements at $25^{\circ} \mathrm{C}$.

\begin{tabular}{lrr}
\hline Oxide/Carbide & $\begin{array}{c}\Delta \boldsymbol{H}_{\text {ds }} \\
(\mathbf{k J} / \mathbf{m o l})\end{array}$ & $\begin{array}{c}\Delta \boldsymbol{H}_{\text {f,el }} \\
(\mathbf{k J} / \mathbf{m o l})\end{array}$ \\
\hline Corundum $\left(\mathrm{Al}_{2} \mathrm{O}_{3}\right)$ & $107.4 \pm 0.2^{1}$ & $-1675.7 \pm 1.3^{2}$ \\
Molybdenum trioxide $\left(\mathrm{MoO}_{3}\right)$ & $-17.8 \pm 0.4$ & $-745.2 \pm 0.4^{2}$ \\
Molybdenum carbide $\left(\mathrm{MoC}_{0.5}\right)$ & $-860.6 \pm 33.1^{\text {this work }}$ & $-26.65 \pm 0.7^{3}$ \\
Quartz $\left(\mathrm{SiO}_{2}\right)$ & $39.4 \pm 0.4^{1}$ & $-910.7 \pm 1.0^{2}$ \\
Water $\left(\mathrm{H}_{2} \mathrm{O}\right)$ & $68.9 \pm 0.1^{1}$ & $-285.8 \pm 0.1^{2}$ \\
\hline
\end{tabular}


Table S2. Thermochemical cycle to calculate the dehydration enthalpies of $\mathrm{Mo}_{2} \mathrm{C} / \mathrm{FAU}$ samples at $25{ }^{\circ} \mathrm{C}$.

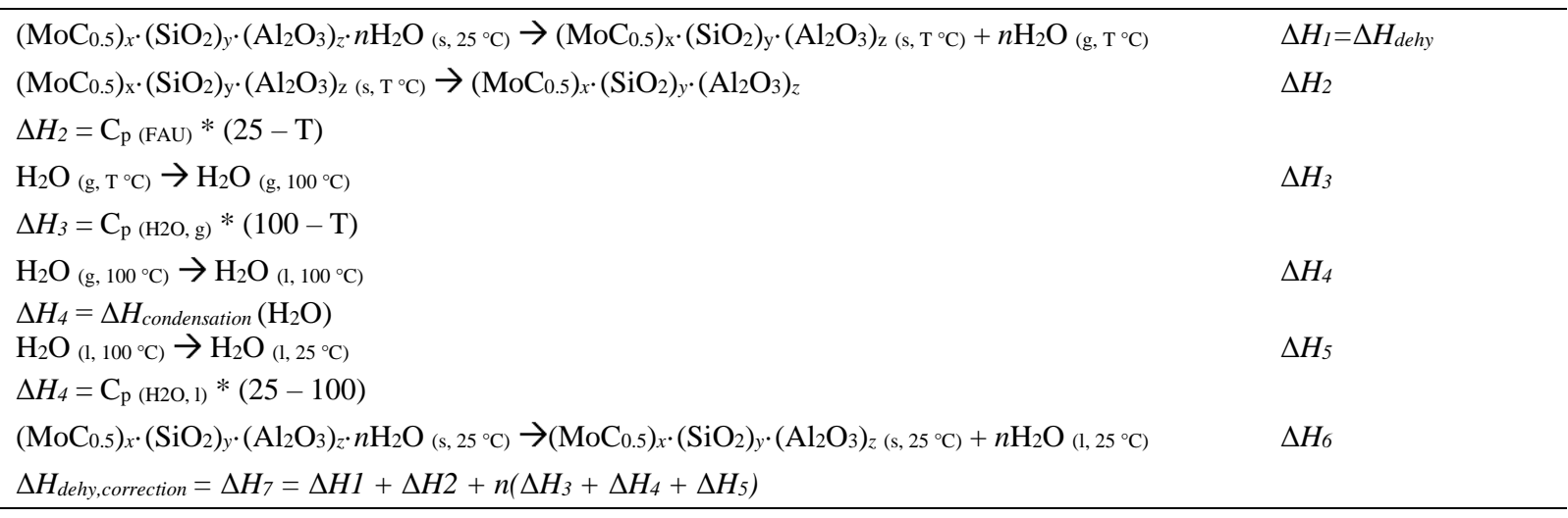

The approximation is that the dehydration happen at constant temperature $\mathrm{T}$ and $\mathrm{T}$ is the

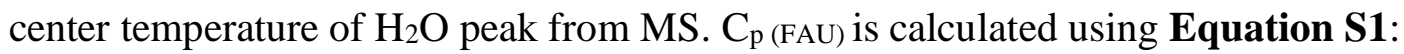

$C_{p(F A U)}=\frac{m\left(\mathrm{MoC}_{0.5}\right)}{m(\mathrm{FAU})} C_{p\left(\mathrm{MoC}_{0.5}\right)}+\frac{m\left(\mathrm{SiO}_{2}\right)}{m(\mathrm{FAU})} C_{p\left(\mathrm{SiO}_{2}\right)}+\frac{m\left(\mathrm{Al}_{2} \mathrm{O}_{3}\right)}{m(\mathrm{FAU})} C_{p\left(\mathrm{Al}_{2} \mathrm{O}_{3}\right)} \ldots \ldots \ldots \ldots$ Equation S1

\section{References}

1. Navrotsky, A. Progress and New Directions in Calorimetry: A 2014 Perspective. J. Am. Ceram. Soc. 2014, 97 (11), 3349-3359. https://doi.org/10.1111/jace.13278.

2. Robie, R. A.; Hemingway, B. S.; Thermodynamic Properties of Minerals and Related Substances at $298.15 \mathrm{~K}$ and $1 \mathrm{Bar}\left(10^{5}\right.$ Pascals $)$ Pressure and Higher Temperatures. U.S. Government Printing Office, Washington D.C., U.S. 1995. https://doi.org/10.3133/b2131.

3. Johnson, G. K.; Hubbard, W. N.; Storms, E. K. The Enthalpies of Formation $\mathrm{Mo}_{2} \mathrm{C}$ (c) by Fluorine Bomb of $\mathrm{Mo}_{2} \mathrm{C}$ (c) Calorimetry. J. Chem. Thermodyn. 1977, 9, 1021-1026. https://doi.org/https://doi.org/10.1016/0021-9614(77)90178-1. 